\title{
I.A. Nell
}

\section{WOMEN ON LEADERSHIP? PERSPECTIVES FROM POSTGRADUATE THEOLOGY STUDENTS THROUGH THE LENSES OF SOCIAL IDENTITY}

\begin{abstract}
${ }^{1}$
South Africa has experienced a long history of patriarchal leadership in the spheres of politics, economics and culture as well as in the sphere of religion, in particular. Many factors influence the current state of religious leadership and the accompanying identity formation. This article aims to do a descriptive-empirical investigation into some of these processes of leadership based on feedback from female postgraduate theology students at the Faculty of Theology, Stellenbosch University, South Africa. The empirical results will be read through the lenses of Social Identity Theory, in order to establish, with keen interest, whether the concepts we are using are still adequate and to seek the possibility of new understandings of religious leadership identities that might emerge and ways in which it can become part of curriculum development.
\end{abstract}

1 Paper delivered at a One-day Conference on Women and Leadership: Reflections on Gender, Religion and Education, hosted by The Circle of Concerned African Women Theologians in Partnership with EFSA (Ecumenical Foundation of South Africa), 16 August 2013, Library Auditorium, University of the Western Cape.

Prof. I.A. Nell, Practical Theology and Missiology, Stellenbosch University, South Africa. E-mail: ianell@sun.ac.za 


\section{INTRODUCTION}

Desmond Tutu, Beyers Naudé, Alan Boesak, Kwame Bediako ... These are some of the names that echo when one thinks of religious leaders in South Africa. Africa is the birthplace of mankind; science traces the first forms of human life back to this continent (Van Zyl 2009:12). Africa ${ }^{2}$ has shown its immense talent, not only on the sports field but also in literature, art, technology, innovation, and theology. Over the past few decades, Africa has produced nine Nobel laureates, six of whom for peace prizes (Van Zyl 2009:14).

Yet, the absence of women among these names is obvious and it becomes even more obvious when one considers the statistics in the religious sphere. Hendriks et al.'s (2012:26-27) recent publication provides a summary of the gender representation in church offices and seminaries that form part of NetAct. ${ }^{3}$ In the second table, the list indicates the total number of pastors in the 25 churches, along with the number of women serving as pastors: "The 25 churches have in total 5835 pastors, of whom 274 are woman. Thus $4.7 \%$ of the pastors in these churches are women." (Hendriks et al. 2012:26)

\section{AIMS OF THIS ARTICLE}

This article aims to shed some light on religious leadership in Africa, in general. I shall first investigate the concept and the different perspectives that emerge from the literature. Secondly, I shall examine some perspectives that emerge from the literature as far as women in leadership within the African context are concerned. Thirdly, I shall explore the use of some of the concepts from Social Identity Theory (SIT) as a contribution within the "relational and constructionist paradigms" towards the discourse on women and religious leadership in Africa. I shall then use the concepts from SIT to develop some research questions for a group of women doing postgraduate studies at the Stellenbosch University. Finally, I shall interpret the data from the semi-structured questionnaires through the lenses of leadership constructs and SIT to evaluate some of the data-produced perspectives on leadership.

2 In this instance, the reference is to Africa. The article will mainly focus on South African leadership.

3 NetAct is the Network for African Congregational Theology, with 12 seminaries participating in the activities of the network. 


\section{THE CONCEPT OF RELIGIOUS LEADERSHIP}

According to Bolden and Kirk (2009:69), the leadership construct has, and always will be, a contested concept. There is no clear-cut general agreement on what leadership entails. Jinkins (2012:308) points to the contested nature of leadership language within a religious discourse:

Though leadership has been an essential aspect of religious life from antiquity, its precise role and significance remain contested to this day in the academy and the church.

In his opinion, one of the main reasons lies in the very definition of the term and the fact that the ways in which the concepts and forms are utilised in many churches "bear[s] the marks of secular ages, especially derived from business, social sciences, and political studies".

Bolden and Kirk (2009) developed four categories that not only provide a framework for the categorisation of different leadership theories, but can also help clarify some of the conceptual contestation with respect to religious leadership:

- Essentialist theories are positioned in an objectivist paradigm, which focuses on identifying leadership traits and behaviours. Leadership is considered to be situated within the person and identity of the leader.

- Relational theories state that leadership resides within the relationship between leaders and followers, and not so much within the leaders themselves. Leadership is, therefore, a group quality. These theories emphasise emergent leadership processes and the distribution of influence and expertise among leaders and followers.

- Critical theories focus on the influence that power and political dynamics have in communities and organisations. This sceptical perspective contends that leadership is the outcome of social and psychological processes. Leadership is used to maintain power and status, rather than to empower followers.

- Constructionist theories evaluate how leadership constructs meaning and helps people make sense of situations. Leadership, therefore, resides in narratives, and the leader helps the community reframe its understanding of social problems. These theories emphasise the leader's capacity to solve problems.

This basic framework provides a platform for understanding the complexity of religious leadership in the African context. It is a multidimensional concept that has no universal definition or agreed upon content 
(Bolden \& Kirk 2009:70). Various researchers have ascribed different meanings to Afro-centric leadership approaches.

When one specifically observes women in leadership within the African context, different perspectives emerge when the literature is reviewed, thus confirming that this phenomenon can be studied through different theoretical lenses. I shall now discuss some of these perspectives.

\section{WOMEN IN LEADERSHIP}

\subsection{The role of patriarchy}

Castells (1997:88) discusses in detail the way in which patriarchy operates as the founding structure of all contemporary societies. Africa has been challenged for centuries by the crises facing this model. Volumes of books have been written on the topic and suffice it to say in this regard that Castells roots patriarchy in its more general forms and in its diverse manifestations, within the context of the family. In his opinion, patriarchy is the most pervasive social institution in recorded history and consists of two elements, namely the dominance of men over women, with the family as the institutional core in which the dominant positions belong to the pater familias, and "compulsory heterosexuality", where the influence of patriarchy extends far beyond family life and pervades all institutions of life, including religious life.

However, Castells is convinced that, in the new network society, there is a breakdown of the traditional patriarchal family and the consequent compensations and substitutes for this. It is not quite clear to what degree this is happening in Africa and South Africa. Some scholars are of the opinion that patriarchy is still alive and well, at least in some of the African countries (Phiri 1992, 1997, 2009).

\subsection{Processes of inculturation}

According to Bosch (1991:447), inculturation takes place, because "[t]he Christian faith never exists except as 'translated' into a culture". With the missionary movements and Western colonialism, it is obvious that the church and its leadership structures have been the bearers of culture. In this regard, cultural and religious perceptions of patriarchy and leadership have become what the churches practise, enact and preach. This silent acceptance of colonial modernity is typical of the entire continent of Africa ${ }^{4}$

4 Cf Kobia (2003; 2006). 
and becomes most obvious in the leadership structures of the churches that originated from the missionary movements.

Phiri (1997:43) writes that, "when Christianity came to Africa, it came as male dominated. Anything that was incompatible with this perspective was crushed. When the Dutch Reformed Church Mission came to Central Malawi, women were excluded from being evangelists, deacons and elders". In her reflection on the way in which the synodical structures operated, Phiri (1997:69) came to this sad conclusion: "When the Synod denied leadership roles in the church to women, what they were saying to them is that they were not of the right gender to be used by God in that capacity."

\subsection{The role of Scripture and tradition}

Claassens (2012:149), along with many other Biblical scholars, points to the way in which "biblical texts play a key role in forming and sustaining a worldview where the males in society are privileged and thus in power". She goes on to point to the patriarchal world view, in many of the Biblical texts, which "contributes to a worldview in contemporary society where the same would be said to be true. In this regard, many women and men have internalized these values and worldview reflected in the biblical text and cannot look at the text (or their world) in any other way."

In part of a course on teaching gender at Stellenbosch University, Claassens helps the students understand in what ways feminist biblical interpretation serves as tool to deconstruct the power of the text to uphold patriarchal values, helping to understand the equality of male and female so that full humanity may be achieved and illustrate in what ways a reconstructed reading of the texts "may serve as a powerful source of resistance in the fight for gender justice" (Claassens 2012:150).

\subsection{The leadership labyrinth and glass ceiling}

It becomes apparent from the literature that the fourth conceptualisation of women in leadership within the African context is known as the "leadership labyrinth", referring to "the invisible barrier preventing women from ascending into elite leadership positions" (Northouse 2010:305). According to Northouse (2010:305), research found that even in female-dominated occupations, women face the glass ceiling, whereas men (usually White men) appear to ride the "glass escalator" to the top leadership positions.

Once again, noting the statistics provided by Hendriks (2012:27) through the lenses of the leadership labyrinth, this becomes even more obvious if one views the scenario concerning gender representation in 
church offices and seminaries. In some institutions such as the CCAP: Nkhoma Synod in Malawi, Hefsiba in Mozambique, NETS in Namibia and RTS in Nigeria, there is not a single woman in the leadership structures of these institutions and supporting churches.

To conclude this section, leadership by women in Africa, viewed through the perspectives of patriarchy, inculturation, the role of Scripture and tradition as well as the so-called leadership labyrinth and glass ceiling, portrays a bleak picture. As noted earlier, Bolden and Kirk (2009:70) propose an emphasis on the relational, critical and constructionist theories in stimulating activities that promote dialogue and the sharing of experiences, with the goal of eliciting new insight and understanding into African leadership. In the next section, I shall explore Social Identity Theory (SIT) as a theory in which one finds a combination of the relational, constructionist and critical theories. I shall then proceed to the empirical section of the research on women in leadership positions.

\section{SOCIAL IDENTITY THEORY}

\subsection{Introduction}

Social Identity Theory (SIT) is a combination of the relational, constructionist and critical theories put forward by Bolden and Kirk (2009). The origins of SIT are found in the pioneering work of Henri Tajfel and John Turner (Haslam et al. 2011:45-64). At the heart of this approach to the study of social groups, there is the notion of "social identity", i.e. "an awareness that one belongs to a particular social group and that this group membership is important and meaningful" (Tajfel et al. 1979:35). One can determine why social identity is important for this study, by asking the question that leaders of religious groups would want to ask: Why do people become part of a group? In answer to this, Turner et al. (1987), for example, found that human beings become part of a group on a personal level, because they really want to, and, on a group level, because they believe that it is the right thing to do.

\subsection{Phases in theory formation}

According to Haslam et al. (2011:50), theory formation around social identity developed through two phases. Tajfelet et al. (1979:36) found that, in the initial phase, human beings accept a certain group identity as their own in terms of their subjective self-definitions, and that they tend to describe their own group favourably by positively distinguishing it from other groups in terms of their own values. This is called "positive 
distinctiveness". Many factors come into play with positive distinctiveness. There is always a connection between the nature of the group and the social context, and the meaning of social identity can shift depending on whom the group compares itself to. This brings us to the second phase in the theory forming of social identity, namely self-categorization theory.

\subsection{Self-categorization theory}

A study by Turner et al. (1987:38-39) clearly shows that self-categorization or self-definition plays the biggest role in group attendance. Thus, we participate in group activities to the extent that it is possible for us to think of ourselves as "we" and not just "I". While the SIT forms the basis for the action of the group, the self-categorization theory emphasises the psychological process that underlies the transition of behaviour - that is the behaviour that is informed by a person's understanding of his/her social identity. This leads to the argument that, because definitions about identity have such important social and political consequences, leaders seek ways in which to use these definitions for their own purposes. They often have to work hard to determine a specific version of identity. In this regard, images, metaphors, narratives and anecdotes play an important role.

\section{EMPIRICAL RESEARCH}

\subsection{Research design}

The research design for my empirical research works with an interpretive perspective in qualitative research, with its roots in hermeneutics as the study of the theory and practice of interpretation (Henning et al. $2010: 19-21)$. This kind of empirical research aims to provide contextually valid descriptions and interpretations of human actions based on an insider's perspective of people and their world. The research was done by means of a semi-structured interview schedule (eight questions) with a sample of students in faith communities where they exercise different leadership functions.

SIT formed the basic theoretical framework for the development of the semi-structured questionnaire. As part of the questions, I asked the interviewees to describe and to tell stories in what Henning et al. (2010:53) call "someone's narrative version of her lived experience (as in the phenomenological interview)". Semi-structured interviews, allowing openness for narrative and lived experience, still need to be interpreted in order to make sense of the data. 
Many students from a rich variety of backgrounds and contexts enrol annually for the Postgraduate Diploma in Theology at Stellenbosch University. The diversity of contexts of these students includes countries (culture and language), denominations, social locations, leadership positions, gender, and so on. I shall address two basic research questions. What does one learn about religious leadership from these students that are unique to their communities. What are the most important images on leadership they use $?^{5}$ I decided to take the intake of students during 2012 and 2013 as my unit of analysis.

The population of students is in the vicinity of 20 women students, but I only made use of the responses of 10 students, making certain that they do come from different denominational, age and social backgrounds. ${ }^{6}$ The respondents are the following:

- Respondent 1: Lay member (serving on Church Board), Anglican Church, rural area in Northern Kwazulu-Natal (middle aged).

- Respondent 2: Youth pastor, Dutch Reformed Church, rural area in the Overberg (middle twenties).

- Respondent 3: Lay member (chair of the Church Board), Uniting Reformed Congregation, Cape Flats (Heideveld) (middle aged).

- Respondent 4: Lay member, Dutch Reformed Church, rural area in the Ceres valley (early thirties).

- Respondent 5: Youth pastor, United Presbyterian Church in South Africa, rural area in Southern Kwazulu-Natal (middle aged).

- Respondent 6: Lay member, Baptist Church, northern suburbs of Cape Town (middle aged).

- Respondent 7: Lay member Anglican Church, southern suburbs of Cape Town (middle aged).

- Respondent 8: Lay member, Anglican Church, Hermanus (middle aged).

- Respondent 9: Youth worker, Dutch Reformed, Stellenbosch (middle twenties).

5 The two questions form part of a questionnaire consisting of eight questions that explore different aspects of leadership from a Social Identity perspective. I only scrutinised the responses to questions 1 and 6 .

6 In the literature, this is called 'random sampling': "For a probability sample, each member of the population has a known chance of being included in the sample, and random sampling is the best-known means for accomplishing this" (Given 2008:799). 
- Respondent 10: Lay member, Seventh Day Adventist, Cape Flats (Guguletu) (middle aged).

One of my assumptions was that most of the data would represent "essentialist theories" in light of the fact that the majority of the literature on leadership in Africa concentrates on trait and style theories of leadership. I decided not to pay attention to all the answers to the questions, but rather to concentrate on the answers to two of the eight questions. ${ }^{7}$

\subsection{Research findings and coding of the data8}

\section{Question 1}

You are in conversation with a group of friends. Someone starts to speak about his/her congregation. Describe how you would define to them what makes your congregation unique and in what way does it differ from other congregations in your vicinity? The following are the three most prominent codes that emerged from the analysis of the data, along with some examples.

\section{Code 1: The Church as place open to all (lay involvement and hospitable)}

Many of the respondents view their churches as places where they experience "openness" and the opportunity for lay involvement ...

Die gemeenteraad bestaan uit lidmate van die kerk wat in leiersposisies staan en die vergaderings is oop vir enige lidmaat, so het die hele gemeente toegang tot besluite wat in die kerk gemaak word en elkeen se stem tel (Respondent 2). ${ }^{9}$

The uniqueness of our congregation can be ascribed to a number of factors. These include our involvement in the community, our

$7 \quad$ Space does not allow the researcher to pay attention to the other questions. It is hoped, however, that the data in these answers will be used for further research in the field of leadership.

8 Inductive content analysis was used for analysing the data (Creswell 2005). The coding process started with an initial reading of the text, dividing it into segments and identifying codes, and then reducing or combining codes into themes.

9 Translation: The Church Board, which is open to any member, consists of members of the congregation who serve in positions of leadership. In this way, the entire congregation does have access to decisions being taken and each person's voice counts. 
openness to change, the fact that the members are very hospitable and our "warm worship services" on a Sunday (Respondent 3).

In my congregation we like to speak about 'disciples' rather than merely the 'Church-goers'. Such recognition thus brings the ministry focused on the laity, so that every congregation member, both the officers and laity, proactively joins in various church ministries according to their spiritual gifts (Respondent 6).

\section{Code 2: The Church as promoter of care, health and well-being} Some of the respondents pointed to the church's involvement in promoting health and well-being:

My congregation values culture and taking care of the environment. One of my congregation's projects is Take Care. It takes care of the elderly and the disabled. The biggest challenge for my congregation is HIV/AIDS and poverty. It therefore has plans to expand Take Care project to include issues of combating HIV/AIDS. My congregation has integrated some of the cultural practices into the church. These are: rituals concerning burials, birth, wedding and the virginity test. This is done with the aim of preventing HIV/AIDS and helping our youth from immoral practice (Respondent 5).

The lifestyle promoted in my faith community is different. We are encouraged to live as vegetarians. For those who still eat meat is an exception. One of our major tasks is to spread the health message to the entire world (Respondent 10).

\section{Code 3: The Church as identity bearer}

Two of the respondents pointed to the important role of the church in identity formation, although both formulated it negatively:

Ek ervaar dat die gemeente op die oomblik ' $n$ identiteitskrisis beleef. Die amptelike visie van die gemeente is missionaal van aard, maar in praktyk vind daar nie werklike praxis van die missionale, lewendige drie-enige God deur die gemeente as liggaam van Christus plaas nie. Die fokus in die gemeente is nie op die onderskeiding van God se wil vir die huidige situasie van die gemeente nie, maar wel eerder op behoud en rehabilitasie (Respondent 4). ${ }^{10}$

10 Translation: I feel that our congregation is currently experiencing an identity crisis. The formal vision of the congregation is missional, but, in practice, there is not a missional praxis through the living Tri-une God as body of Christ. The 
Our style of worship is rather conservative compared to other communities of faith; even the singing is from hymnals with notes, while other Churches mainly sing choruses (Respondent 10).

\section{Question 6}

When you think about the minister(s) and/or the Church Board, what would you say is the image of them in the community? Can you record an incident or experience to illustrate your thoughts? The following are the four most prominent codes that emerged from the analysis of the data, along with some examples:

\section{Code 1: The minster as "respected, servant and comforter"}

It is interesting to note how many of the respondents referred to essentialist and relational notions such as respect, service and comforting when reflecting on the leadership:

We have a new and young minister at our church - has only been in the community for just over a year, but I would say that he has a positive image in the community. He has been a wonderful source of comfort to many un-churched families in times of grief/death, which has resulted in many new members of the church. The traditional denominational churches are still being used for funerals, weddings and baptisms by many nominal Christians, and he has been very good at using these services as a way of drawing new congregants (Respondent 1).

The one word that pops up is "respected". Pertaining to our particular situation we have decided to be transparent in everything we do. Between me as chairperson and the scribe, we try to keep the members informed and up to date so that they hear it first-hand. There is also a sense of unity amongst the board and that counts in our favor (Respondent 3).

Wanneer ek egter na die leraar as individu kyk is daar wel ' $n$ ander beeld wat uitstaan. Dit is die beeld van ' $n$ man met baie groot hande wat op sy knieë voor die gemeente, tussen die kinders gaan sit om ' $n$ boodskap aan hulle te bring, wat sy hande uitsteek en seën oor die kinders uitspreek, wat die gemeente kinders met die hand en op die naam groet op ' $n$ Saterdag in die dorp. Dit is ' $n$ beeld

focus of the congregation is not on the discernment of God's will for the current situation, but rather on maintenance and rehabilitation. 
van deernis en toeganklikheid, dit is ' $n$ beeld van Jesus tussen die mense (Respondent 4). ${ }^{11}$

Minister is a God servant in that sense he/she presents God to the community as the servant, not a king, but the one who should serve the community because minister's duty is to render service to the community. In order for the community to see God, the minister should serve the congregation and also the community (Respondent 5).

Ministers are people that are put aside by God for his work (Respondent 10).

\section{Code 2: The minister as "shepherd and prophet"}

As could be expected, some Biblical images also appear in the data, again pointing to essentialist, but also critical perspectives:

For a minister, two images are overlapped in my mind: Shepherd and Prophet. While the former represents the dimension of loving care, saying, 'one flock under the one shepherd', the latter signifies the perspective of justice, urging, 'repentance and the reorientation of life.' The congregation, however, needs both images. One sense, the congregation wants to become 'sheep' under the peaceful protection of the shepherd. The other sense, they also long for the prophetic minister who is able to lead them until they become 'soldiers' of Christ (Respondent 6).

\section{Code 3: The Church Board as "working behind the scene"}

Some of the respondents referred to the work of the Church Board as not so obviously visible to the wider community, but working together, stressing relational notions of leadership:

I would have to say that the image of our Parish Council in the community would probably be non-existent! In our church itself, many of the congregants would battle to name any of the Council members. Historically, an Anglican Parish Council is in charge of

11 Translation: When I look at the minister as an individual, there is another image that comes to the fore. This is the image of a person with big hands standing on his knees in front of the congregation, sitting among the children to bring a message to them, strectching out his hands to bless them, greeting the children by hand and knowing their names when he sees them on Saturdays in town. This is the image of compassion and availability; it is an image of Jesus among the people. 
overseeing the finances and administration of the local church - this role it probably does, but in a very quiet, behind the scenes manner. We do however, have committed Churchwardens, who meet weekly with the minister and who are probably more well-known in the community - a banker, an agricultural engineer and a DA ward councillor and have a wider influence within the community than the Parish Council itself (Respondent 1).

Ons Visiegroep is tans aan die beplan aan ons gemeente se missionale doelwitte, deelnemende eredienste, betekenisvolle verhoudingsgroepe en pastorale sorg (Respondent 2). ${ }^{12}$

There is also a sense of unity amongst the board and that counts in our favour (Respondent 3).

Members of the congregation and the board of management are from the community; they are there to serve the church and also represent their community. They know what is going on in the community; that can help a minister work together with them to serve the community and communicate with them (Respondent 5).

\section{Code 4: The leadership is "hierarchical, naïve and out of touch"}

Some of the respondents described the Church Board as distant, hierarchical, naïve and out of touch:

Die beeld van die ouderlinge en diakens in ons kerk wat in hul swart en wit klere met wit in afsondering voor in die kerk sit, spreek van die ou, konvensionele, ontoeganklike hiërargiese sisteem binne die kerk (Respondent 4). ${ }^{13}$

I would say that they are generally considered to be godly and hard-working people. However, in complete frankness, I believe that in the faith community, as well as the community outside the church, they are often considered to be naïve and out of touch with culture (Respondent 7).

12 Translation: Our vision group is currently planning our congregation's missional purpose, participating worship services, meaningful relational groups and pastoral care.

13 Translation: The image of the elders and deacons in our congregation, sitting in their black and white clothes isolated from the rest in the front pews of the church, tells a story of an old, conventional, unapproachable and hierarchical system in the church. 
Since our new rector arrived just over a year ago, great changes have taken place. The church council [had] consisted of people from the "main" church who had held the position for many years and they "ruled". The communities in the "township churches" were largely ignored or at best treated somewhat paternalistically. Under his leadership the composition of the parish council has changed to give equal representation to all three congregations. He is striving to unify the church (Respondent 8).

\section{INTERPRETATION OF THE DATA}

The interpretation of the analysed data is related to the research questions (Mason 2002:183-187). The following two research questions directed the research in this article. With regard to religious leadership, what does one learn from these women students that are unique to their communities. What are the most important images on leadership they use? The different aspects pertaining to the uniqueness of faith communities and images of leadership became categories in the analysis of the interview data.

\subsection{Different perspectives on the uniqueness of faith communities}

In this article, the findings relating to "What makes your congregation unique?" clearly support the notion that some interesting perspectives could be found in the "self-categorization" (SIT) of the respondents. It is clear that the faith communities, to which these students belong, play a very important role in terms of promoting care, health and well-being. In addition, if one links this role with the important emphasis on community development, one understands why authors such as Swart, Nieman and Erasmus point to the enormous role that Faith-Based Organizations (FBOs) play in social and community development (Swart et al. 2010). The social capital generated through communities of faith cannot be underestimated.

The majority of the respondents described their faith communities as a place that is open to all and that the opportunity is there for all to participate in the activities and in leadership roles. Words such as "warm worship services", "involvement in the community", "hospitable members", "disciples", "spiritual gifts" all emphasise essentialist and relational notions of leadership. In line with the previous comment, some of the respondents also pointed to the church as promoter of care, health and well-being, as they care for the elderly and the disabled. The problem and challenge of HIV/AIDS was also addressed. 
One respondent experienced her congregation as a place where they are struggling with their identity. She experiences something of a discrepancy between what is projected as the vision of the congregation and the real praxis of the faith community. She finds that the focus is more on maintenance than on trying to discern the work of the Triune God. This is a good example of more constructionist and critical notions towards identity and leadership. However, it is the only example of these notions among the respondents.

\subsection{Tensions of multiple leadership images}

I assumed that, in the data related to the "image of the leader", I would find several references to the traits and behaviours concerning the person and identity of the leader, named "essentialist theories". Although there were references to concepts of power and authority (hierarchy), it was surprising to note that concepts related to "relational theories" were more frequent in the data. As far as images of the leader as "comforter and servant" are concerned, it was interesting to observe how the image of leadership in service of the community was emphasised. Concepts related to "constructionist theories" and "critical theories" did not really feature in the data.

\subsection{Constructing (new) identities for women in positions of leadership}

In conclusion, the following common themes can be identified as part of constructing new identities for women who aspire to participate in religious leadership.

- Leadership and respect: The data shows convincingly that the "calling" of the leader and being respected for that is an important aspect of taking up the leadership role in these communities.

- Leadership and relations: The importance in the data of fellowship, the experience of "belonging", taking care of each other, especially the elderly and the disabled, all point to the central importance of relations.

- Leadership and service: The realisation that leadership is not, in the first instance, self-serving, but in service of others (the community) was very prominent in the data. Theories on "servant leadership" can help further explore identity construction in this regard, although some people have reservations about and even resist using this concept. ${ }^{14}$

14 Many view the concept of servant leadership (especially in Africa) as very taboo. Servant leadership theory has not had the same reception as it did in 
- Leadership and gender-studies in the curriculum of the Postgraduate Diploma: The fact that only two respondents referred to aspects of hierarchy, naivety and being out of touch with culture can be interpreted in different ways:

- The role of the lecturer/researchers: The way in which the questions were put, might not have evoked any reference to power, patriarchy and hierarchy. They might have anticipated what the lecturer was looking for and what would please him to participate in a conversation about the research field. ${ }^{15}$

- The material read in preparation for the conversation: The prescribed work (Hendriks 2004) might not have referred to the specific problem of patriarchy. He does, however, refer to the problem of hierarchy and clericalism (Hendriks 2004:14).

- The lack of students' critical thinking capabilities: The students might not yet have been trained in critical thinking skills, accepting the material prescribed by the lecturers as the "truth" and trying to memorise the content in order to pass the examination.

Although one or more of these arguments might help understand some of the students' responses, the absence of any references to gender inequalities (patriarchy), the leadership labyrinth and inculturation, implies that a great deal still needs to be done concerning more critical and constructive thinking with regard to the curriculum of this specific programme. ${ }^{16}$

A good example of the way in which it could be done, albeit on a lower level of complexity (HQF - level 8), is the way that first Denise

the West. According to Kretzschmar (2002:47), the term servant can be very confusing for many Africans, because it carries with it a great deal of negative connotations. The word servant has often been associated with the word slave. So, not only does the word slave represent very negative memories, it also does not suit a culture that esteems powerful leaders. Therefore, many Christians in Africa can find it hard to accept the concept of servant leadership, especially when it runs against the grain of their own culture. This becomes another factor perpetuating the Christian leadership crisis in Africa.

15 Ethical clearance for this research was obtained from the Research Committee of the Faculty of Theology. It was classified as low-risk research because of the nature of the research.

16 Although questions were asked about the curriculum per se, it is assumed that the programme should alter the students' perceptions, but that the intended outcomes of the programme may be different? The findings may suggest that women view leadership relationally. This might point to the way in which women value certain qualities in leaders. This also ties in with the self-categorisation section of identity theory discussed earlier. 
Ackermann and for the past three years, Julie Claassens, developed a module on "Gender, Culture and Scripture" as part of the Masters of Divinity in the Faculty of Theology, Stellenbosch University. Claassens (2012:147-158) wrote a chapter Teaching gender at Stellenbosch University in the book Men in the pulpit, Women in the pew? Addressing gender inequality in Africa (Hendriks et al 2012), in which she gives a detailed description of the way that she goes about teaching the course.

\section{CONCLUSION}

Women aspiring to become religious leaders within the African context remain a complex phenomenon. Although different perspectives of religious leadership in Africa were identified, concepts on religious leadership in Africa still need more clarification. Some unique features were, however, discovered. Bolden and Kirk (2009) are of the opinion that greater attention should be paid to understanding the leadership discourse that shapes African identities and moves African people to action. With the help of categories of leadership theories, different leadership perspectives, SIT and some (more) empirical work, I hope to contribute to the discourse on women in religious leadership in African contexts, specifically in the way it might help highlight the desperate need for the transformation of women leadership identities that have to take place in the African context.

\section{BIBLIOGRAPHY}

BOLden, R. \& KIRK, P.

2009. African leadership: Surfacing new understandings through leadership development. International Journal of Cross Cultural Management 9(1):69-86.

Bosch, D.J.

1991. Transforming mission: Paradigm shifts in theology of mission. Maryknoll, NY: Orbis Books.

Castells, M.

1997. The power of identity: The information age: Economy, society and culture. Vol. II. Oxford: Blackwell Publishing.

ClaAssens, J.

2012. Teaching gender at Stellenbosch University. In: H.J. Hendriks, E. Mouton, L. Hansen \& E. Le Roux, Men in the pulpit, women in the pew? (Stellenbosch: Sun Press), pp. 131-146.

Creswell, J.W.

2005. Educational research: Planning, conducting, and evaluating quantitative and qualitative research. Upper Saddle River, NJ: Pearson Merrill Prentice Hall. 
Given, L. M. (ED.) 2008. The Sage encyclopedia of qualitative research methods. Thousand Oaks, CA: Sage.

Haslam, S.A., Reicher, S. \& Platow, M.

2011. The new psychology of leadership: Identity, influence, and power. Town, Sussex: Psychology Press.

HendRiks, H.J.

2004. Studying congregations in Africa. Wellington: Lux Verbi.

Henning, E., Van Rensburg, W. \& Smit, B.

2004. Finding your way in qualitative research. Pretoria: Van Schaik.

JINKINS, M.

2012. Religious leadership. In: Miller-McLemore (ed.), Wiley-Blackwell companion to practical theology (Oxford: Wiley-Blackwell), pp. 308-317.

KoBIA, S.

2003. The courage to hope: The roots for a new vision and the calling of the Church in Africa. Geneva: World Council of Churches.

2006. Called to the one hope: A new ecumenical epoch. Geneva: World Council of Churches.

KRETZSCHMAR, L.

2002. Authentic Christian leadership and spiritual formation in Africa. Journal of Theology of Southern Africa 113:41-60.

Mason, J.

2002. Qualitative researching. London: Sage.

Northouse, P.G.

2010. Leadership: Theory and practice. $5^{\text {th }}$ ed. London: Sage.

PhIRI, I.A.

1992. African women in religion and culture: Chewa women in the Nkhoma Synod of The Church of Central Africa Presbyterian. Doctoral Thesis: University of Cape Town.

1997. Women, presbyterian and patriarchy: Religious experiences of Chewa women in Central Malawi. Blantyre: Assemblies of God Press.

2009. Major challenges for African women in theological education (1989-2008). International Review of Mission 98(1):105-119.

Swart, I., Rocher, H., Green, S. \& Erasmus, J.

2010. Religion and social development in post-apartheid South Africa: Perspectives for critical engagement. Stellenbosch: Sun Press. 
Tajfel, H., Turner, J., Austin, W.G. \& Worchel, S. 1979. The social psychology of intergroup relations. In: W.G. Austin \& S. Worchel (Eds.), An integrative theory of intergroup conflict (Monterey, CA: Brooks Cole), pp. 33-47.

Turner, J.C., Hogg, M.A., OAKes, P.J., Reicher, S.D. \& Wetherell, M.S. 1987. Rediscovering the social group: A self-categorization theory. Oxford: Basil Blackwell.

VAN ZYL, E. 2009. Leadership in the African context. Cape Town: Juta.

Keywords

Woman

Leadership

Social identity
Trefwoorde

Vroue

Leierskap

Sosiale identiteit 